\title{
NEW TRIALS OF USE OF MOLASSES AND GARLIC EXTRACTS FOR COMPATING MYCOTOXICOSIS
}

\author{
Atef, A. Hassan * and Mogeda, K. Mansour ** \\ *Mycology and Mycotoxins Department, Animal Health Research Institute \\ ${ }^{*}$ Biochemistry Department, Animal Health Research Institute
}

\begin{abstract}
Two hundreds and fifty samples of feeds (125 of each of ingredients of plant origin "yellow corn, white corn, soya bean, soya bean meal, wheat and beans" and compound manufactured feed and animal protein concentrates (meat-bone meal, fish meal, poultry offal and mixed feed). Samples were collected from various poultry farms at Giza and Cairo Governorates. Fungal isolation from ingredients of plant origin revealed lower rate of mould contamination in comparison to compound manufactured feed and animal protein concentrates. For instance, Aspergillus species was isolated from 48-68\% and 80-100\% of feed ingredients and animal concentrates respectively. This findings was correlated with higher levels of mycotoxins in manufactured feed and animal protein concentrates than feed ingredients of plant origin. For aflatoxins and ochratoxin $A$ the mean levels in feed ingredients were ranged from (18-31 ppb and 15-28 ppb, respectively), while in manufactured feed and animal protein concentrates they ranged from (23-42 ppb and 32-47 ppb) respectively.The isolated Aspergillus flavus and A. ochraceus produced significant levels of respective mycotoxins. The induction of aflatoxicosis and ochratoxicosis in quails with particular reference to their partial elimination by garlic and molasses were carried out. The changes in biochemical parameters (AST, ALT, ALP, LDH, total lipid, triglyceride, cholesterol, $L D L, H D L$ and VLDL), also in serum total protein and protein electrophoresis due to aflatoxicosis and roved under supplementation

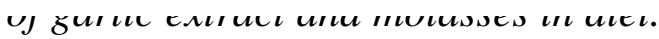


Up to date the high productivity of animal and poultry gain essential goal in the improvement of the human life. Hence all relating elements including health of feed and feeding become interesting factors to be study. Recently in developing countries the offal of abattoir, fish byproduct and unsuitable meat for human consumption are used for feed manufacture for animal and poultry. These products carry a dangerous toxic factors which affect the animal health (Bendell et al., 1985). Fungi and mycotoxins pollution increased in manufactured feed and animal protein concentrates than ingredients of plant origin (Mahmoud, 1993; Adebejo et al., 1994; Skrinigar et al.,1995 and Casstell'a et al.,1999). It causes many disease problems in human and animal particularly respiratory affections, Alimentary Toxic Alukia,Teratogenic, Dermatogenic and Carcinogenic diseases which reflected directly on the performance and health of man and animal (Viscoli et al., 1990; Li et al., 1999; Kubena et al., 1999 and Wang et al., 2000).

The aflatoxin (AF) and ochratoxin A (OA) were considered to be most important dangerous mycotoxins, possess acute and chronic toxicity depending on dosage and on species of animals (Dihter, 1984 and Jones, 1993). Several workers had documented the toxicity of ochratoxin and the relative lack of toxicity of aflatoxin in Japanese quails (Doster et al., 1973 and Chang and Hamilton, 1982). Ochratoxin A is a mycotoxin that has been demonstrated to be approximately three more time toxic to game birds (Ringnck phesant) than aflatoxin (Ruff et al., 1992). Aflatoxin are secondary fungal metabolites that can be produced by Aspergillus flavus and A. parasiticus. Whereas ochratoxin A is the most prevalent one produced by Aspergillus ochraceus. The main toxic manifestations of these toxins are hepatotoxicosis, nephrotoxicosis, immunosuppressive, oxidative damage, alterations in serum constituent, enzyme activity and carcinogenesis that can link to aflatoxicosis and ochratoxicosis in various species of animals (Ruff et al.,1992; Edrington et al., 1995; Hochler and Marquardt, 1996; VinitketKumnuen et al., 1999 and Rastogi et al., 2001). Hence, the use of safe methods to the animal health to eliminate the toxic effects of aflatoxin and ochratoxin become critical demand. The most recent method is the use of natural

$\overline{\text { Kafr El-Sheikh Vet. Med. J. Vol. } 1 \text { No. } 1 \text { (2003) }}$ 
substance as garlic and molasses (Dowd and Shen, 1991 and Kirubaharan et al., 1999).

Therefore, the present study, aimed to investigate the prevalence of moulds and their toxins in single natural feed and those manufactured from waste product. The most predominant mycotoxins were employed for the purpose of their elimination by garlic and molasses. The biochemical parameters of laboratory animals were taken as indicator for detection the efficiency of all treatments.

\section{MATERIALS \& METHODS}

\section{Feed samples:-}

Two hundred and fifty feed samples were collected from poultry farms at Cairo and Giza Governorates. They include two main types:-

A.Ingredients of plant origin (yellow corn, white corn, soya bean, wheat and beans), 25 samples of each.

B.Animal protein concentrates and compound manufactured feed (meat-bone meal, fish meal, poultry offals, mixed feed and Soya beans meal) (25 samples of each).

\section{Quail chicks:-}

Seventy healthy Japanese quail one day old were kindly obtained from private farms at Alexandria Governorate. They were kept in wire floored brooder batteries with electric heat and constant lighting. Feed and water provided ad libitum.

\section{Preparation of garlic extract and molasses:-}

The garlic pulps were broken into cloves. These cloves were washed in sterile distilled water and dried on a filter paper. They were crushed in juice crusher and the juice collected. To the garlic, tryptic soya broth was added to a ratio 1:4 and mixed will using a magnetic stirrer for 30 minutes and centrifugated at $8000 \mathrm{rpm}$ for 60 minutes. The supernatant was filtered through a membrane filter. The extract prepared was used on the same day (Kirubaharan et al., 1999). 
For molasses the obtained crude extract from sugar cane manufactories was used as it is (Churchil et al., 2001).

Screening of samples for fungal contamination (ICMSF, 1978 and Conner et al., 1992):-

At least $1 \mathrm{~kg}$ of each feed was finally ground in electric grinder and a desired amount taken for mycological and mycotoxicological examination.

\section{Isolation and identification of fungi (ICMSF, 1978):-}

Each sample was moistened and held at room temperature until heavy growth was observed. Suspension of each of these commodities were made in 1/4 strength Ringer's solutions by blending and then 10 fold serial dilutions were prepared. One $\mathrm{ml}$ portions of each dilutions of each sample inoculated in sterile petri dishes (each containing $15 \mathrm{ml}$ malt extract agar containing oxytetracycline).

\section{Incubation and reporting the result:-}

The plates were then incubated 7-10 days at 25-28:C and examined visually. Individual colonies were selected, purified and briefly identified according to macroscopic and microscopic characters as reported by $\boldsymbol{A l}$ doory (1980); Refai (1988); Raper and Fennel (1965); Smith and Yarrow (1988) and Thomas and Carter (1990).

Production of aflatoxin by A. flavus and ochratoxin A by A. ochraceus in yellow corn (Trenk et al., 1971 and Benett, 1979):-

250 gm of yellow corn was dispensed in 2 liter flasks and autoclaved for $15 \mathrm{~min}$. at $121^{\circ} \mathrm{C}$. The flasks were inoculated with conidial suspension of $A$. flavus (in case of aflatoxin) and A. ochraceus (in case of ochratoxin). The moisture content of flask was raised by addition of distilled water to $30-40 \%$. The flasks were incubated at $30^{\circ} \mathrm{C}$ for 15-30 days before extraction of toxin.

\section{Extraction of aflatoxin and ochratoxin:-}

Aflatoxin and ochratoxin from $50 \mathrm{gm}$ portions of feed were extracted as mentioned by (Basil et al., 1981). Methanol: water (55:45) was used as primary extraction solvent before purification and clean up $\overline{\mathrm{Kafr} \text { El-Sheikh Vet. Med. J. Vol. } 1 \text { No. } 1 \text { (2003) }}$ 
by chloroform. The immunoeffenity column loaded and developed according to the recommended procedures by Hansen (1993). After development of all columns, they were observed under U.V. light and photographed or its content is dissolved in methanol to be measured by fluorometer.

Experimental elimination of Aflatoxicosis and ochratoxicosis by garlic extract and molasses (Doster et al., 1973; Ruff et al., 1992; Kirubaharan et al., 1999; Parlet et al., 1999 and Curchil et al., 2001):-

The quail chicks were divided into seven groups (ten of each) and maintained for 3 weeks period for experimental work. The design of treatment and doses of all materials were shown in table (1)

Table (1): Experimental design of the elimination of ochratoxicosis and Aflatoxicosis by garlic and molasses.

\begin{tabular}{|c|c|c|c|c|c|c|c|}
\hline Treatment & G1 & G2 & G3 & G4 & G5 & G6 & G7 \\
\hline Aflatoxins (total) 2 ppm & - & + & + & + & - & - & - \\
\hline Ochratoxin 2 ppm & - & - & - & - & + & + & + \\
\hline Garlic 5\% of total diet & - & - & + & - & - & + & - \\
\hline Molases $5 \%$ of total diet & - & - & - & + & - & - & + \\
\hline Healthy diet & + & - & - & - & - & - & - \\
\hline
\end{tabular}

\section{Blood sampling:-}

Blood samples were collected at end of experiment and centrifuged at $3000 \mathrm{rpm}$ for 5 minutes and then the sera were kept in deep freeze at $-20^{\circ} \mathrm{C}$.

\section{Biochemical analysis:-}

Sera were used for measuring the concentration of total proteins (Sonnen-wirth and Jareet, 1980), protein electrophoresis pattern (Davis, 
1964 and Ornstein, 1964). Total lipids, cholesterol, triglyceride, HDL, LDL described according to Knight et al. (1972), Watson (1960); Gordon and Amer (1977) and Pesce and Kapplan (1987), respectively.

Activities of alanine aminotarnsferase (ALT) and aspartate aminotransferase (AST) were determined according to Reitman and Frankel (1957); alkaline phosphatase (ALP) were determined according to Refield and Goldbery (1971). The determination of urea were conducted according to Wybenga et al. (1971) and creatinine as described by Gaoria (1974). All kits from BioMerieux including lipids and liver enzymes.

The obtained data were statistically analysed using t-test after Petrie and Watson (1999).

\section{RESULTS \& DISCUSSION}

The mycoflora of feed ingredients of plant origin (white, yellow corn, Soya bean, Soya bean meal, wheat and beans) revealed isolation of 5 genera of moulds. Genus Aspergillus was the predominant isolates (60, $52,52,48,68 \%)$ followed by Penicillium (20, 20, 12, 12, 8\%). A. flavus and $A$. ochraceus were the most frequent species persisted in samples. Whereas other genera including (Fusarium, Rhizopus and Mucor) rarely isolated. The same findings were observed in many previous studies (Ahmed, 1993; Abd El-Fattah, 1994 and Jand and Singh, 1995 and Desjardins et al., 2000).

These cereals which were used as a source of diet for human and animal contained few mould contaminants (Table, 2) in comparison to the animal protein concentrates which were used recently in animal feeding(meat-bone meal,fish meal,poultry offal and mixed feed)(Table,3) which when subjected to isolation of fungi a relatively large number of mould were isolated. Nine genera of fungi were isolated from these feed samples.Aspergillus and Mucor isolated from all samples of compound manufactured feed and animal concentrates with particular reference to A. flavus, A.ochraceus and A. candidus which predominantly species isolated.For instance, in meat and bone meal.A.flavus was present in $100 \%$ of samples,A.ochraceus present in $60 \%$ of samples and A. candidus was Kafr El-Sheikh Vet. Med. J. Vol. 1 No. 1 (2003) 
isolated from $32 \%$ of samples. Whereas A.niger,A. glucuas, A. terrus and A. fumigatus were rarely isolated species $(24,12,4$ and $0 \%)$ respectively. Other genera of fungi were frequently present Penicillium (68\%), Rhizopus (16\%), Fusarium (8\%), Rhodotorula (8\%), Scopulariopsis (4\%), Cladosporium (4\%) and Alternaria (0\%)). Regarding genera of Penicillium and Fusarium, P. citreanum; P. implicatum and P. digitatum, $F$. moniliforme and $F$. poea were isolated from manufactured and animal concentrates samples. Generally, these levels of fungal contamination in meat and bone meal was nearly observed in other manufactured feed (fish meal, poultry offal and mixed feed) (Table, 3). These findings were detected previously by Mahmoud (1993) in mixed feed (Saber, 1993) in Marketed manufactured feed (Skrinijar et al., 1995). El-Far et al. (1993) who detected the over incidence of fungal contamination near $83 \%$ in bone meal, fish meal, blood meal and concentrates.

Comparison between mycoflora of feed ingredients in table (2) and compound manufactured and animal protein concentrates feed (Table, 3) revealed that the manufactured compound feed were relatively higher in contamination this may be due to many reasons related to the source of feed, changes of environmental factors, procedures of production and transportation to the place of animal rearing. All these factors play an important role in increasing the fungal contamination of manufactured waste products (Fish meat, meat bone meal, mixed feed and poultry offal. These products may have a useful compound for animal health but the presence of microbial contamination which give a chance for toxin production and decaying of protein and vitamins contents affect the animal health (Deiner et al., 1976; Abramson et al., 1983 and Park and Bullermon, 1983).

Table (4) and (5) reported mycotoxins contamination of ingredients and compound manufactured animal protein concentrates feeds. All samples of both types of feeds had a various levels of aflatoxins and ochratoxins. Otherwise, the rate of aflatoxin contamination in feed ingredient varies from 8-20\% of samples with the mean levels of (18-31 $\mathrm{ppb}$ ), whereas the same toxin in compound manufactured animal protein concentrates had the range of (48-60\%) with mean levels of (23-42 ppb).

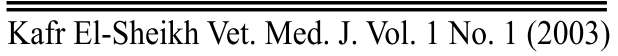


These observations also seen in ochratoxin contamination which ranged from (4-12\%) of feed ingredient at mean levels of (15-28 ppb). However in manufactured compound and animal protein concentrates feed ranged from $(32-48 \%)$ at mean levels of (42-67 ppb). Other mycotoxins as zearalenon and $\mathrm{T} 2$ had also the same pattern of contamination. These results come in parallel with (El-Far et al., 1993; Abdebajo et al., 1994; Jimenez et al., 1996 and Nikulin, 1996).

The higher toxins contamination of compound manufactured waste product increased the health hazard and danger of their consumption by animals (Hsu et al., 1972). This also may be due to the unknown sources of single materials which used in manufacture of compound feed.

The waste product used as meat, bone, fish and offal suggested to be from diseased animals which appeared as clear high contamination by mould and mycotoxins and reflected as disease outbreak or bad productivity of animal. Whereas the ingredients of plant origin from natural cereals which not exposed to various unhygienic handling and reflected as high quality of feed which had low relative contamination of cereals in contrary of manufactured waste product (Tables, 2, 3, 4 and 5). To fulfill our above suggestion the predominant isolates in this study A. flavus and A. ochraceus screened for mycotoxins production to support the results in Table (2-5). While, the A. flavus which isolated from ingredients of plant origin produced aflatoxin at rate ranged from $20-50 \%$ at mean levels of (20-31 ppb) (Table, 6). The isolates from compound feed and animal protein concentrates product produced aflatoxin at rate ranged from (60-80 \%) at mean levels of (27-52) (Table, 7).

The isolates of $A$. ochraceus from cereals yielded ochartoxin at rate ranged from (12.5-40\%) with mean levels of (22-41 ppb). In contrary, the isolates from compound manufactured animal protein concentrates feed from waste product had levels of ochratoxin of(40-70\%)(40-61 ppb) (Tables, 8 and 9). These results supported by (Bendel et al.,1985; $\mathbf{L i ,} 1999$ and Wang et al., 2000).

The damage of liver and kidney are the main dangerous effects of aflatoxins and ochratoxin A in animals and poultry (Dihter,1984; Bendel 
et al., 1985 and Jones, 1993). These effects are due to selective suppression of the activity of natural killer cells (Pegram and Waytt, 1986). Other problems due to the moulds and their toxins would be recorded including, teratogenic, dermatogenic and carcinogenic effects to human and animal (Viscoli et al., 1990; Lie et al., 1999 and Wang et al., 2000).

For preservation of all types of feeds from these contaminants trials of using natural materials of no side effect on hygienic quality of animal product was become of critical recommendation. Garlic (Allium sativum) is one of the common additive in food and the molasses which used as a source of trace elements and vitamins for human (Kirubaharan et al., 1999 and Churchil et al., 2001). The trial of elimination of aflatoxin and ochratoxin by molasses and garlic was conducted in Japanese quails.

The biochemical changes in quails due to aflatoxicosis and ochratoxicosis shown in table (10) which shows significant increase in serum enzyme activities (AST, ALT, ALP and LDH). Similar findings were obtained by Badawy et al. (1996) and Mobarak et al. (1996) in Japanese quails and Sahar and El-Meadawy (2001) in broiler chickens.

This may be due to necrosis of hepatic cells and release of these enzyme into circulation (Lyuch et al., 1971). Such hepatic toxic effect of aflatoxin attributed to its active metabolite in liver as expoxide, Netke et al. (1997) which covealently bind to DNA and may affect structural and enzymatic protein function (Culler and Newbern, 1994). Ochratoxin and aflatoxin are a protein synthesis inhibitor that have an affect on mitochondrial oxidative enzyme activity (Marquardt and Frohlich, 1992). The aflatoxin had adverse effect on liver cells more than ochratoxin. Inversely ochratoxin found to be has greater toxic effect on the kidney than aflatoxin. This was expressed as a significant increase in serum urea and creatinine (Table, 10). These results were attributed to a significant alteration in tubular function caused by aflatoxin or ochratoxin (Ruff et al., 1992; Badawy et al., 1996 and Mobarak et al., 1996).

$\overline{\text { Kafr El-Sheikh Vet. Med. J. Vol. } 1 \text { No. } 1 \text { (2003) }}$ 
Treatment with garlic and molasses (groups 3, 4, 6 and 7) led to reduced enzyme activities. This protective action of garlic may be due to the presence of dially sulfied which conjugated with epoxid and decrease the degenerative effects induced by aflatoxin or ochratoxin (Jeong and Lee,1998 and Helen et al., 1999). Yeast and vitamins are considered as molasses constituent which counteracted the toxic effect of aflatoxins (Churchil et al., 2001) and other mycotoxins (Dowd and Chen, 1991). Aflatoxin and ochratoxin induced a severe effect on serum biochemistry of quails which were represented by significant decrease of total lipids, triglyceride, cholesterol, HDL-C and VLDL-C, where a significant increase well be noticed in LDL-c (Table, 11). These abnormalities may be attributed to hepatocellular injury induced by aflatoxin or ochratoxin were the liver is the major source for plasma Total lipid, lipid profiles and lipoproteins (Tietz, 1996). As well as, mycotoxins binding to DNA leading to inhibition of RNA polymerase allowing inhibition of lipid synthesis and transport, Donaldson et al. (1992) and Weibking et al. (1993). Following garlic or molasses supplementation, partially ameliorated the toxic effect of aflatoxin or ochratoxin (groups 3, 4, 6 and 7). Garlic extract decreased total cholesterol, LDL-cholesterol, increase HDL-C, reduction of triglyceride and VIDL (Siegel et al., 1999 and Zhang et al., 2001).

Molasses contain a large amount of trace element such $\mathrm{Cu}, \mathrm{Zn}, \mathrm{Mn}$, e.t.c. and some vitamin like B-complex such these constituents are catalysts for oxidative enzyme of liver and decrease the adverse effects of aflatoxin or ochratoxin (Awadallah et al., 1984 and Webster et al., 1996).

In regards to serum total protein and electrophoretic pattern (Table, 12).Our observation demonstrated an apparent significant decrease in the total protein, prealbumin, albumin, total alpha, total beta and total globulin as well as A/G ratio among quails fed on diets supplemented with aflatoxin or ochratoxin (groups 2,5). Similar results were also recorded by Badawy et al. (1996) and Sahar and El-Meadawy (2001). Aflatoxin or ochratoxin causes inhibition of DNA and protein synthesis as well as immunosuppressive due to the inflammation, cirrhosis of liver and nephrotoxic effect (Harvey et al., 1990 and Tietz, 1996).

$\overline{\text { Kafr El-Sheikh Vet. Med. J. Vol. } 1 \text { No. } 1 \text { (2003) }}$ 
The globulin component (Table, 13) showed significant drop in $\alpha 1$, $\beta 1$ and $\beta 2$ globulin with significant increase in $\alpha 2, \gamma 1$ and $\gamma 2$ globulins. This result correlated with Burguera (1983) Tietz, 1996).

Supplementation of garlic and molasses induced good effect that minimize the alterations of serum protein and its fraction due to aflatoxin or ochratoxin (Groups G3, G4 and G7) Table (13).

Dially sulfied of garlic inhibit the activity of cytochrom P-450 (Oxidative metabolism) which activated by aflatoxin or ochratoxin. So its inhibition produced immunosppressive effects on humarol and cellular response (Jeong and Lee, 1998). Yeast as a competent of molasses has the same effects on the cytochrome P-450 (Sengslag and Wurgler, 1994). Also molasses contain vitamin B-complex in high concentrations this well restored the activity of B-globulin which decreased by mycotoxins (Harvey et al., 1990).

It is become apparent that the levels of mould and their toxin contamination observed significantly in compound manufactured animal protein concentrates from waste products reflected the bad methods of manufacturing of feed which used a waste unhygienic materials in industry of animal feeds. In addition, contamination of diet with aflatoxin or ochratoxin caused alteration of serum Japanese quails as enzyme activities, kidney function, T. lipids, Lipid profiles, T. protein and its fractions. The supplementation of Garlic extract or molasses improve these biochemical changes. This attributed to the presence of Dially sulfide of garlic and trace elements and vitamins of molasses. 
Table(6):Screening of A. flavus isolated from single natural feed for production of aflatoxins.

\begin{tabular}{||l||c|c|c|c|c||}
\hline \multirow{2}{*}{ A. flavus isolated from:- } & \multicolumn{5}{|c|}{ Aflatoxins (ppb) } \\
\cline { 2 - 6 } & No. of +ve & $\%$ & Max. ppb & Mean ppb & Min.ppb \\
\hline White corn & $5 / 10$ & 50 & 33 & 22 & 18 \\
\hline Yellow corn & $3 / 10$ & 30 & 36 & 31 & 23 \\
\hline Soya bean & $3 / 10$ & 30 & 24 & 20 & 15 \\
\hline Wheat & $2 / 10$ & 20 & 25 & 23 & 20 \\
\hline Beans & $2 / 10$ & 20 & 44 & 22 & 16 \\
\hline Soya bean meal & $5 / 10$ & 50 & 42 & 30 & 20 \\
\hline
\end{tabular}

Table(7):Screening of A. flavus isolated from manufactured poultry and animal waste products for production of aflatoxins.

\begin{tabular}{|l||c|c|c|c|c||}
\hline \multirow{2}{*}{ A. falvus isolated from:- } & \multicolumn{5}{|c|}{ Aflatoxins (ppb) } \\
\cline { 2 - 6 } & No. of +ve & $\%$ & Max.ppb & Mean ppb & Min ppb \\
\hline \hline \multirow{2}{*}{ Fish meal } & $7 / 10$ & 70 & 56 & 32 & 45 \\
\hline \multirow{2}{*}{ Meat and bone meal } & $8 / 10$ & 80 & 65 & 41 & 52 \\
\hline \multirow{2}{*}{ Poultry of glows } & $6 / 10$ & 60 & 48 & 32 & 43 \\
\hline Mixed feed & $6 / 10$ & 60 & 30 & 21 & 27 \\
\hline
\end{tabular}

$\overline{\overline{\text { Kafr El-Sheikh Vet. Med. J. Vol. } 1 \text { No. } 1 \text { (2003) }}}$ 
A,A.Hassan. \& M,K.Mansour.

Table (8): Screening of A. ochraceus isolated from ingredients of plant origin for production of ochratoxins.

\begin{tabular}{||l||c|c|c|c|c||}
\hline \multirow{2}{*}{ A. ochraceus isolated from:- } & \multicolumn{6}{|c|}{ Ochratoxins (ppb) } \\
\cline { 2 - 7 } & No. of +ve & $\%$ & Max. ppb & Mean ppb & Min. ppb \\
\hline \hline \multirow{2}{*}{ White corn } & $0 / 5$ & - & - & - & - \\
\hline Yellow corn & $1 / 5$ & 20 & 30 & 30 & 30 \\
\hline Soya bean & $1 / 5$ & 20 & 41 & 41 & 41 \\
\hline Wheat & $2 / 5$ & 40 & 45 & 36 & 40.5 \\
\hline Beans & $1 / 8$ & 12.5 & 22 & 22 & 22 \\
\hline Soya bean meal & $6 / 10$ & 60 & 30 & 28 & 23 \\
\hline \hline
\end{tabular}

Table(9):Screening of A. ochraceus isolated from manufactured feed from waste product for production of ochratoxin.

\begin{tabular}{|l||c|c|c|c|c||}
\hline \multirow{2}{*}{\multicolumn{1}{|c||}{ A. ochraceus isolated from:- }} & \multicolumn{5}{|c|}{ Ochratoxins (ppb) } \\
\cline { 2 - 6 } & No. of +ve & $\%$ & Max.ppb & Mean ppb & Min. ppb \\
\hline \hline \multirow{2}{*}{ Meat and bone meal } & $7 / 10$ & 70 & 65 & 46 & 50 \\
\hline Fish meal & $5 / 10$ & 50 & 47 & 32 & 40 \\
\hline Poultry offal & $6 / 10$ & 60 & 42 & 33 & 44 \\
\hline Mixed feed & $4 / 10$ & 40 & 53 & 43 & 47 \\
\hline
\end{tabular}

$\overline{\overline{\text { Kafr El-Sheikh Vet. Med. J. Vol. } 1 \text { No. } 1 \text { (2003) }}}$ 


\section{REFERENCES}

- Abdel-Fattah, A.M. (1994): "Public health hazard of myco-contamination of some cereals to human and animal health." Assiut Vet. Med. J., 31(61): 209-215.

- Abramson, D.; Mills, J.T. and Boycott (1983): "Mycotoxin and mycoflora in animal feedstuffs in Western Canada." Can. J. Comp. Med., 47 (1):23-26.

- Adebajo, L.O.; Idowu, A.A. and Adesanya, O.A. (1994): "Mycoflora and mycotoxins production in Nigerian corn and corn based snakes." Mycopathologia, 126 (3): 183-192.

- Ahmed, S.K. (1993): "Mycoflora changes and aflatoxin production in stored black gram seeds." J. Stored Prod. Res., 29 (1): 133-136.

- Al-Doory, Y. (1980): "Laboratory Medical Mycology." Lea Febiger Philadelphia Kimpton Publishers, London, pp., 357-367.

- Awadallah, R.M.; Sherif, M.K.; Mohamed, A.E. and Grass, F. (1984): "Determination of trace elements of Egyptian Cane sugar (Naga Hammady Factories) by neutron activation, atomic absorption spectrophotometric and inductively coupled plasma-atomic emission spectrometric analysis." Int. J. Environ. Anal. Chem., 19: 41-53.

- Badawy, S.A.; Mubarak, M.S. and Ahmed, Y.F. (1996): "Reproductive and pathological changes due to ochratoxicosis in laying Japanese quail." J. Union Arab. Biol., 5: 293-311.

- Basil, A.R.; Edward, M.G. and Deryck, S.P.P. (1981): "Rapid economic method for determination of aflatoxin and ochratoxin A in animal feed." J.A.O.A.C., Vol. 64, No. 4.

- Bendele, A.M.; Carlton, K. and Lillehoje (1985): "Ochratoxin A carcinogenesis in $\left(57 \mathrm{~B}_{1}, 16 \mathrm{JX} \mathrm{Ch}\right) \mathrm{F}_{1}$ mouse." J. National Cancer Inst., 75: 737742 .

- Benett, J.W. (1979): "Aflatoxins and anthraquinones from diploids of $A$. parasiticus." J. Can. Microbiol., 113: 127-136.

- Burguera, J.A.; Edds, G.T. and Osuna, O. (1983): "Influence of soleniumon aflatoxin B1 or crotalaria toxicity in turkey poult." Am. J. Vet. Res., 44: 1714-1717. 
- Castell'a, G.; Bragulat, M.R. and Cabones, F.J. (1999): "Fumonisin production by Fusarium species isolated from cereals and feeds in Spain." J. Food Prot., 62 (7): 811-813.

- Chang, C.F. and Hamilton, P.B. (1982): "Experimental Aflatoxicosis in young Japanese quails." Poult. Sci., 61: 869-874.

- Churchil, R.R.; Mohan, B. and Viswanlhan, K. (2001): "Effect of live yeast culture in alleviating the toxicity of aflatoxin in broiler chickens." Ind. Vet. J., 78 (2): 116-118.

- Conner, D.E.; Samson, R.A.; Hoching, A.D.; Pitt, J.I. and King, A:D. (1992): "Evaluation of methods for the selective enumeration of Fusarium species in food stuffs." Modern Method in Food Mycology Development in Food Sci., 229-302.

- Cullen, J.M. and Newberne, P.M. (1994): "The toxicity of aflatoxin, human health, veterinary and agricultural significance." $2^{\text {nd }}$ Ed., Academic Press, Philadelphia.

- Davis, B.Z. (1964): "Disc electrophoresis. II. Method and application to human serum proteins.” Ann. N.Y. Acad. Sci., 121: 404-427.

- Desjardins, A.E.; Manandkar, G.; Planttner, RD.; Maragos, C.M.; Sheestha, K. and McCormick, S.P. (2000): "Occurrence of Fusarium species and mycotoxins in maize and wheat and the effect of traditional processing methods on mycotoxin levels." J. A Food Chem., 48 (4): 1337713383.

- Diener, U.L.;Davis, N.D.and Morgan, J.G. (1976): "Nature and importance of mycotoxins in grains, Biodeterioration of material." Vol. 3, Sherplay, I.M. and Kaplan, A.M. (Eds), App. Science Publisher Ltd, Essex, England.

- Dihter, C.R. (1984): "Risk estimates of liver cancer due to aflatoxin exposure from peanuts and peanuts product." Food Chemistry Toxicology, 122: 431-437.

- Donaldson, W.E.; Tung, H.T. and Hamilton, P.B. (1992): "Depression of fatty acid synthesis in chick liver (Gallus Domesticus) by aflatoxin." Comp. Biochem. Physiol., 41: 843-847.

- Doster, B.C.; Arscott, G.H. and Smith, P. (1973): "Comparative toxicity of ochratoxin A and crude Aspergillus ochrecus culture extract in Japanese quails (Caturnix coturnix).” Poult. Sci., 52: 235 1-2353.

$\overline{\text { Kafr El-Sheikh Vet. Med. J. Vol. } 1 \text { No. } 1 \text { (2003) }}$ 
- Dowd, P.F. and Shen, S.K. (1991): "The contribution of yeast to toxin resistance of the cigarette beetle (Lasioderma serricorne)." EntomologiaExperimentalis-et-Applicata, 59: 241-248.

- Edrington, T.S.; Kubena, L.F.; Harvey, L.F. and Rottinghous (1995): "Influence of a super activated charcoal on the toxic effects of aflatoxin and T-2 toxin in growing broiler." Poult. Sci., 76: 1205-1211.

- El-Far, F.A. and Saleh, N.; Hegazi, S.M. and Aziz, N.H. (1993): "Some important health significant studies on the imported poultry feedstuffs." Impact Food Research on New product development (1993) Organized by Food Science and Technolo-section, Department of Applied Chemistry Univ. of Karachi, Karachi, Pakistan.

- Giario, J.D.(1974):"Principles and Techniques."Harper and Raw,Hagstoun.

- Gordon, T. and Amer, M. (1977): "Colorimetric determination of HDL." J. Med., 62: 707.

- Hansen, T.J. (1993): "Quantitative testing for mycotoxins." Am. Ass. Cereal Chemist. Inc., 38 (5): 5-15.

- Harvey, R.B.; Kubena, L.F.; Elissade, M.H.; Carrier, D.E.; Huff, W.E.; Rottinghaus, G.E. and Phillips, T.D. (1990): "Effect of treatment of growing swine with aflatoxin and T-2 toxin."Am.J.Vet. Res.,51:1688-1693.

- Helen, A.; Rajasrec,C.R.;Krisknakumar,R.;Augusti,K.T. and Vijayammal, P.L. (1999): "Antioxidant role of oils isolated from garlic (Allium strivum linn) and onion (Allium cepalinn) on nicotine-induced lipid peroxidation." Vet. Hum. Toxicol., 41: 316-319.

- Hochler, D. and Marquardt, R. (1996): "Influence of vitamins E and C on the toxic effects of ochratoxin A and T-2 toxin in chicks." Poult. Sci., 75: 1508-1515.

- Hsu, I.C.; Smallay, E.B.; Strong, F.M. and Ribelin, W.E. (1972): "Identification of T-2 toxin in moldy corn associated with a lethal toxicosis in dairy cattle." Appl. Microbiol., 24: 680-684.

- International Commission on Microbiological Specification for Food (ICMSF) (1978): "Microorganisms in foods." Univ. of Toronto Press, Toronto, Canada. 
- Jand, S.K. and Singh, P.P. (1995): "Fungi associated with poultry feeds and their toxin producing ability." Indian Vet. J., 72 (9): 905-908.

- Jeong, H.G. and Lee, Y.W. (1998): "Protective effects of dially-sulfide on $\mathrm{N}$-nitrosodium ethylamine induce immunosuppression in mice."Cancer Cell, 11 (134): 73-79.

- Jimenez, M.; M'a-nez, M. and Hern'anderz, E. (1996):"Influence of water activity and temperature on the production of zearlenone in corn by three Fusraium species.” Int. J. Food Microbiol., 29 (2-3): 417-421.

- Jones, J.M. (1993): "Food safety." St. Paul. Minn. Eagen Press.

- Joseph, A. and Roger, W.G. (1976):"Clinical Chemistry, Principles and Procedures." $4^{\text {th }}$ Ed., Boston, pp. 168-179.

- Kirubaharan, J.J.; Palaniswami, K.S.; Anbukumar, K. and Mohanas Subramaniam (1999): "In vitro studies on antibacterial effect of crude garlic extract on Escherichia coli." Ind. Vet. J., 76: 797-799.

- Knight, J.A.; Anderson, S. and James, M.R. (1972): "Chemical basis of the suiphosphovanilin reaction for estimating total serum lipids."J.Clin.Chem., 18: $199-210$.

- Kubena, J.F.; Harvey, R.B..; Buckley, S.A.; Bailey, R.H. and Rottinghaus, G.E. (1999): "Effects of long-term feeding of diets containing moniliformin, supplied by Fusarium fujikuroi culture material, and fumonisin, supplied by Fusarium moniliforme culture material, to laying hens." Poult. Sci., 78 (11): 1499-1505.

- Li, Y.C.; Ledoux, D.R.; Bermudez, A.J.; Fritsche, K.L. and Rottinghaus, G.E. (1999): "Effects of fumonisin B on selected immune responses $\mathrm{m}$ broiler chicks." Poult. Sci., 78 (9): 1275-1282.

- Lyuch, M.S.; Shalkop, W.T.; Jacoby, N.M.; Smith, D.F. and Miller, R.W. (1971): "Responses of dairy calves to oral doses of aflatoxin." J. Dairy Sci., 54: 1688 .

- Marquardt, R.P. and Frohlich, A.A. (1992): " A review of recent advances in understanding ochratoxicosis." J. Anim. Sci., 70: 3968-3988.

- Mobarak, M.S.; Badawy, S.A. and Ahmed, Y.F. (1996): "Biological effect of graded levels of dietary aflatoxin B1 with special reference to reproduction in laying Japanese quail." J. Union. Arab. Biol., 5: 251-268.

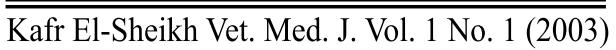


- Mahmoud, A.L.E. (1993): "Toxigenic fungi and mycotoxins content in poultry feedstuff ingredients." J. Basic. Microb., 33 (2): 101-104.

- Netke, S.P.; Roomi, M.W.; Tsao, C. and Niedzwiecki, A. (1997): "Ascorbic acid protects guinea pigs from acute aflatoxin toxicity." Toxicol. Appl. Pharmacol., 143: 429-435.

- Nikulin, M.; Lappalaninen, S.; Pasanen, A.L.; Veijalaninen, P.; Berg, S. and Hintikka, E.L. (1996): "Comparison of detection methods for trichothecenes produced by $F$. sporotrichiodies on fodder and grains at different air humidities." Nat. Toxins, 4 (3): 117-121.

- Ornstein, L.C. (1964): "Disk electrophoresis. 1. Background and Theory." Ann. N.Y. Acd. Sci., 212: 221.

- Park, K. and Bullerman, L.B. (1983): "Effects of substrates and temperature on aflatoxin productions by $A$. parasiticus and A. flavus." J. Food Prot., 46 (3): 178.

- Parlat, S.S.; Yildiz, A.O. and Oguz, H. (1999): "Effect of clinoptillolite on performance of Japanese quail (Coturnix cotur japonica) during experimental aflatoxicosis." Br. Poult. Sci., 40 (4): 495-500.

- Pegram, A.A. and Wyatt, R.D. (1986): "The relationship of certain blood parameters to aflatoxin resistance in Japanese quail." Poult. Sci., 65: 16521658.

- Pesce, J. and Kaplan, A. (1987): "Methods in Clinical Chemistry." Mosby, Missouri, USA.

- Petrie, A. and Watson, P. (1999): "Statistics for Veterinary and Animal Science." $1^{\text {st }}$ Ed., pp. 90-99, The Blackwell Science Ltd, United Kingdom.

- Pettersoon, H.; Hedman, R.; Engstron, B.; Elwinger, K. and Fossum, O. (1995): "Nivalenol in Swedish cereals occurrence, production and toxicity towards chickens." Food Addit. and Contam., 12 (3): 373-376.

- Raper, K.B. and Fennel, D.T. (1965): "The genus Aspergillus." Williams and Wilkins Co., Baltimore Maryland.

- Rastogi, R.; Srivastava, A.R. and Rastogi, A.K. (2001): "Long term effect of aflatoxin B (1) on lipid pervidation in rat liver and kidney: effect of picrolin and Silymarin." Phytothen. Res., 15 (4): 307-310.

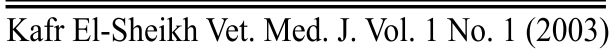


- Refai, M.K. (1988): "Isolation and identification of fungi." Published by Faculty of Vet. Med., Cairo University.

- Refield, A. and Gold-bery, D.M. (1971): "Colorimetric determination of alkaline phosphatase activity." Enzyme, 12: 561.

- Reitman, S. and Frankel, S. (1957):“A colorimetric determination of serum glutamic oxaloacetic and glutamic pyruvic transaminase.”Am. J. Clin. Path., 28:56-58.

- Ruff, M.D.; Huff, W.E. and Wilkins, G.C. (1992): "Characterization of toxicity of the mycotoxins aflatoxin, ochratoxin and T-2 toxin in game birds. III. Babwhite and Japanese quail." Avian Dis., 36: 34-39.

- Saber, S.M. (1993): "Mycoflora and natural occurrence of mycotoxins of chicken stock." Ceatar Univ. Sci. J., 13 (1): 70-74.

- Sahar, A. and El-Meadawy (2001): "Some biochemical studies in hens fed ochratoxin A polluted rations." M. Vet. Sc., Thesis (Biochemistry), Kafr ElShaik, Tanta Univ.

- Sengslage, C. and Wurlger, F.E. (1994): "DNA recombination induced by aflatoxin B1 activated by cytochrome P450-1 A enzyme." Molec. Carcino., 11 (4): 227-235.

- Siegel, G.; Waller, A.; Engle, S.; Walper, A. and Michel, F. (1999): "Pleiotropic effects of garlic." Wien. Med. Wochenschr., 149: 217-224.

- Skrinjar, M.; Ristic, M. and Grbic, Z. (1995): "Contamination of broiler chickens mask and titter with moulds, aflatoxin, ochratoxin and zearalenon." Acta Vet. Hung., 43 (1): 117-124.

- Smith, M.Th. and Yarraw, D. (1988): "Introduction of food born fungi." C.B.S. Beran, B.P., 210-221.

- Sonnenwirth, A. and Jareet, L. (1980): "Garduals Clinical Laboratory Methods and Diagnosis." Vol. 1, $8^{\text {th }}$ Ed., Mosby.

- Thomas, I.I. and Carter, G.R. (1990): "Diagnostic Procedures in Veterinary Bacteriology and Mycology." Fifth Ed., Academic Press, pp. 433-443.

- Tietz, N.W. (1996): "Fundamentals of clinical chemistry." Edited by N.W., Tietz, Saunders Company, Philadelphia, USA.

- Trenck, H.L.; Mary, E.; Butz and Fun sun Chu (1971): "Production of ochratoxin in different cereal product by A. ochraceus." App. Micro., June, p. 1035, Vol. 21, No. 6. 
- Viniketkumnuen, U.; Chewonarin, T.; Dhumitanan, P.; Lerlprasertsuk, N. and Wild, C. (1999): "Aflatoxin-albumin adduct formation after single and multiple dose of aflatoxin B1 in rats treated with Thai medicinal plants." Mutat. Res., 9 (428): 345-351.

- Viscoli, C.; Castagnala, E.; Moroni, G.; Garaventa, A.; Manno, G. and Saviali, C. (1990): "Infection with Fusarium species in two children and neuroblastoma." Eur. J. Clin. Micro. Infect. Dis., 9: 273-276.

- Wang, H.; Wei, H.; Ma, J. and Luo, X. (2000): "The fumonisin $\mathrm{B}_{1}$ content in corn from North China, a high-risk area of oesophageal cancer." J. Environ. Pathol. Toxicol. Oncol., 19 (1-2): 139-141.

- Waston, D. (1960): "Determination of serum cholesterol."Clin. Chem. Acta, 5: 637-645.

- Webster, R.R.; Gawde, M.D. and Bhallacharya, R.K. (1996): "Modulation of dietary copper of aflatoxin B1-induced activity of DNA repair enzymes poly (ADP-ribose) polymerase, DNA polymerase beta and DNA ligase." In vivo, 10 (5): 533-536.

- Weibking, T.S.; Ledoux, D.R.; Brown, T.P. and Rottinghaus, G.E. (1993): "Fumonisin toxicity in turkeys." J. Vet. Diagn. Invest., 5: 75-83.

- Wybenga, D.R.; Digigorgio, J. and Piliggi, V.J. (1971): "Automated method for urea measurement in serum." Clin. Chem., 17: 891-895.

- Zhang, X.L.; Lowe, D.; Giles, P.; Fell, S.; Board, A.R.; Baughan, J.A.; Connors, M.J. and Maslin, D.J. (2001): "A randomize trial of the effect of garlic oil upon coronary heart disease in risk factors in trained male runners." Blood Coagul. Fibrinolysis, 21 (1): 67-74.

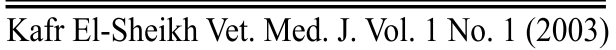


محاو لات حديثة لاستخدام العسل الأسود ومستخلص الثوم فى مقاومة التسمم الفطرى. "عاطف عبد العزيز حسن، **مجدة كامل منصور.

$$
\text { *قسم الفطريات والسموم الفطرية - معهد بحوث صحة الحيوان - الدقى - الجيزة. }
$$

قد تم فحص عدد 250 عينة من العلائق (125 من كلا من:- مكونات العلائق ذات الأصل النباتى "ذرة صفراء وبيضـاء وفول صـويا والقمـح والفول البلدى" والعلائق المركبة ومركزات البروتين

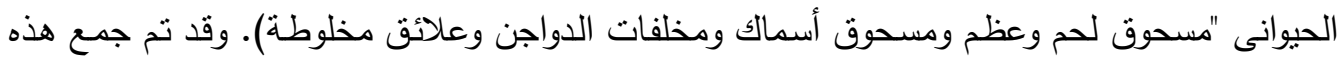
العينات من مزارع الدواجن بمحافظات الجيزة والقاهرة. وقد أفاد العزل للفطريات لمكونات العلائق ذات الأصل النباتى بتواجد التلوث بالفطريات بمعدل منخفض بالمقارعات بداتة بالعلائق المصنعة ومركزات البروتين

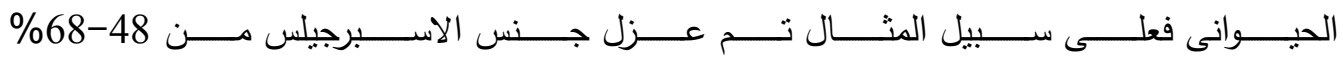
و 80-100\% من مكونات العلائق ومركزات الحيوان على التوالى وقد كانت هذه النتائج مرنبطة بنواجد نسب عالية من السموم الفطرية فى الأعلاف المصنعة ومركزات البرونين الحيوانى بالمقارنة بمكونات

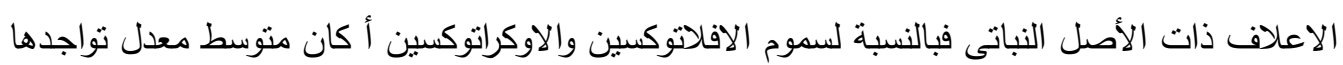
فى مكونات الأعلاف يتراوح بين 18-31 جزء من البليون و 15-28 جزء من البليون على التوالى فى الإنى

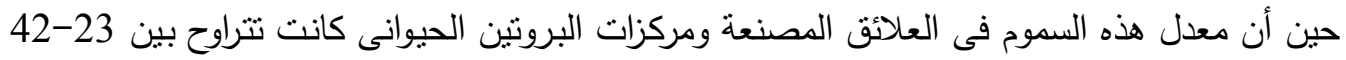
جزء من البليون و 32-47 جزء من البليون على النوالى.

وقد أعطت العترات المعزولة (اسبرجيلس فلافس والاسبرجيلس اوكرايشيس) كميات ملحوظة من

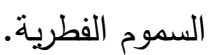
وقد تم استحداث التسمم بسموم الافلاتوكسين والاوكراتوكسين فى طيور السمان واستخدام العسل

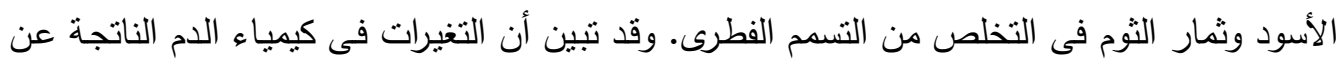

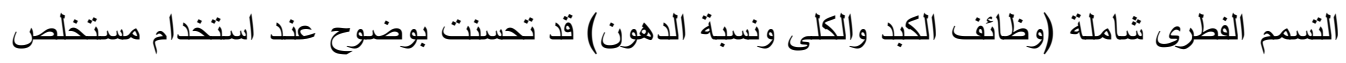
الثوم والعسل الأسود فى الأغذية. 